УДК 330.8

ББК 65.02(0)5

DOI $\underline{10.17150 / 2308-2588 \cdot 2017 \cdot 18(1) \cdot 221-225}$

Е. И. Чибисова

Российский экономический университет им. Г. В. Плеханова, г. Москва, Российская Федерациия

\title{
В ПОИСКАХ НОВОГО МЕТОДА ИЗУЧЕНИЯ ЭКОНОМИЧЕСКОЙ МЫСЛИ
}

Аннотация. Рецензируется монография В. А. Щеголевского «Иерархические структуры и рынок в экономической мысли Запада Нового и Новейшего времени (историко-экономический анализ)». Выделяются основные достоинства и недостатки монографии в рамках дискуссии методе анализа развития экономической мысли. Сделан акцент на осмыслении перехода от методов ранней политической экономии к учению Адама Смита. Проводится сравнение методологии, примененной в работе В. А. Щеголевского, с традиционно принятыми методиками неоинституционалистов в российской экономической науке.

Ключевые слова. Экономическая мысль Запада, рыночная экономика, классическая политическая экономия, учение Адама Смита.

E. I. Chibisova Plekhanov Russian University of Economics, Moscow, Russian Federation

\section{SEARCHING NEW METHOD FOR STUDYING AN ECONOMIC THOUGHT}

Abstract. The article is a review of the scientific monograph of V. A. Shchegolevsky «Hierarchical structure and the market in economic thought of the West of the new and the Latest time (historical and economic analysis)». The author lights the main advantages and shortcomings of the monograph under discussion of 
the method of analysis of the development of economic thought. The review focuses on understanding of the transition from early methods of political economy to the doctrine of Adam Smith. The author compares the methodology applied in the work of V. A. Schegolevsky with the traditionally accepted methods of neoinstitutionalists in the Russian economic science.

Keywords. Economic thought of the West, market economy, classical political economy, the doctrine of Adam Smith.

Работа В. А. Щеголевского ${ }^{1}$ выполнена в своеобразном исследовательском стиле, правда, с применением достаточно распространенных в исторической науке проблемно-хронологического и хронологически-проблемного методов. За основу анализа экономической мысли за 500 с лишним лет ее развития взято противопоставление рынка нерыночным структурам и мотивам поведения (две проблемы, которые почему-то четко не отделены друг от друга в монографии), в силу чего данную книгу можно назвать и трудом по философии экономики. Автор применяет также историко-генетический метод, что выходит за рамки российской традиции написания трудов по истории экономических учений, авторы которых обычно концентрируются на конкретных проблемах. Проблема стоимости в работе В. А. Щеголевского занимает второстепенное место, что также противоречит сложившимся принципам историко-экономического анализа в России.

По сути, автор идет от идей французского институционализма, фокусируя внимание на вопросе отношений между индивидами в обществе, на развитии социальных связей между ними. Влияние французской традиции на социально-экономическую мысль Запада

${ }^{1}$ Щеголевский В. А. Иерархические структуры и рынок в экономической мысли Запада Нового и Новейшего времени (историко-экономический анализ) / В. А. Щеголевский. М. : Креативная экономика, 2016. 313 с. 
занимает в работах В. А. Щеголевского заметное место [4]. Правда, в монографии автор ограничивается, в части французского вклада в экономическую науку, анализом трудов французских авторов лишь XVIII-XIX вв. (C. 61-76). На наш взгляд, работа только выиграла, если бы между прошлым и настоящим французской экономической мысли были бы переброшены мосты, иначе получается, что французский институционализм лишь ощущается в методологическом подходе В. А. Щеголевского, но в то же время его и нет.

Сам вопрос, почему общество часто предпочитает иерархию рынку, то есть, отвергает горизонтальные отношения в сфере распределения доходов и ресурсов, разрабатывается в отечественной экономической историографии давно, если вспомнить работы Р. М. Нуреева, Ю. В. Латова или В. В. Вольчика [1-3]. Однако перечисленные российские неоинституционалисты все-таки исходят из теоретических положений неоклассического анализа, который отказ от рыночного обмена объясняет провалами рынка (теория А. Пигу). В. А. Щеголевский же уходит от неоклассических теорий, обращаясь к социально-экономическим учениям ранних классиков и доклассической политической экономии. В этой связи он правильно устанавливает связь между проблемой частной собственности в трудах Дж. Локка и последующим развитием экономической мысли Запада (С. 68), где длительное время противопоставлялись не капитал и труд, но частная собственность и наемный труд, вокруг чего строились теории взаимоотношений индивидов в обществе. В этой связи В. А. Щеголевский видит разорванность основной линии политической экономии, которая от проблемы распределения собственности ушла в концепцию противопоставления интересов рыночных агентов в идеальной модели экономики Адама Смита. Однако В. А. Щеголевский считает учение А. Смита незавершенным, в этой связи он пишет: «А. Смит так 2017. T. 18, № 1. C. 221-225 
до конца и не разобрался в причинах образования в обществе закрытых и полузакрытых корпораций, имеющих однозначно иерархический тип устройства и заменяющих собой рынок» (С. 242).

Получается, по В. А. Щеголевскому, что «мэйнстрим» экономической мысли отклонился от проработанной философами эпохи Просвещения линии, уйдя в незавершенную теорию А. Смита, которую автор полагает сильно политизированной. В этой связи В. А. Щеголевский рассматривает коллективное действие, как центральный фактор монополизма и олигопольных структур в рыночной экономике (С. 240-250), что противоречит традиционно принятым в неоинституционализме подходам.

Монография В. А. Щеголевского выполнена на высоком научном уровне и должна вызвать внимание научного сообщества. Она может представлять интерес для студентов, аспирантов и преподавателей вузов, как и для всех, интересующихся историей экономической мысли.

\section{Єписок использованной литературы}

1. Вольчик В. В. Культура, поведенческие паттерны и поведенческое мышление / В. В. Вольчик / / Journal of Institutional studies. - 2016. - T.8, № 2. - C. 87-104.

2. Нуреев Р. М. Постсоветское институциональное развитие: в поисках выхода из колеи власти-собственности / Р. М. Нуреев, Ю. В. Латов / / Мир России: социология, этнология. - 2015. - Т. 24, № 2. - С. 50-88.

3. Нуреев Р. М. Россия: особенности институционального развития. - М. : Норма ; Инфра-М, 2016. - 448 с.

4. Попов Г. Г. Республиканизм и формирование концепции экономической свободы / Г. Г. Попов, В. А. Щеголевский // Journal of Institutional studies. - 2014. - Т.6, № 2. С. 27-42.

\section{Информация об авторе}

Чибисова Елена Ивановна - кандидат экономических наук, доцент, кафедра финансового менеджмента, Рос- 
сийский экономический университет им. Г. В. Плеханова, 117997, г. Москва, Стремянный пер., 36, e-mail: TCHibisova. EI@rea.ru.

\section{Author}

Elena I. Chibisova - Ph.D. in Economics, Associate Professor, Financial Management Department, Plekhanov Russian University of Economics, 36, Stremyanny lane, Moscow, Russian Federation, 117997, e-mail: TCHibisova.EI@rea.ru.

\section{Библиографическое описание статьи}

Чибисова Е. И. В поисках нового метода изучения экономической мысли / Е. И. Чибисова / / Историко-экономические исследования. - 2017. - Т. 18, № 1. - С. 221-225. DOI: 10.17150/2308-2588.2017.18(1).221-225.

\section{Reference to article}

Chibisova E. I. Searching new method for studying an economic thought. Istoriko-ekonomicheskie issledovaniya = Journal of Economic History \& History of Economics, 2017, vol. 18, no. 1, pp. 221-225. DOI: 10.17150/2308-2588.2017.18(1).221-225. (In Russian). 